MEDIA BUY OUTS 4

\title{
Is Pacific press freedom really free?
}

The sale of the Daily Post and the draconian decision by a Samoan court to gag the Observer are worrying developments for the Pacific news media.

\section{By INGRID LEARY}

THE START of 1999 has brought worrying developments to the state of media freedom in the Pacific. First came the announcement of the Fiji Government's purchase of 44 per cent of the Daily Post, one of Fiji's two main daily newspapers. Then came a draconian decision by a Samoan court to disallow publication of a story that raised serious questions regarding cash advances and allowances for senior staff from the government-owned airline.

Journalists and international media freedom organisations have condemned both decisions - in Fiji's case, because of concern that people in the Government may attempt to gag the Post from publishing stories critical of the Government, and in the Samoan case, because of the dangerous precedent established.

In each case, those seeking to justify the developments seem to have good reasons - perhaps even genuine intentions - but it's worth considering what's at stake.

In the case of the sale of the Post shares, criticism in varying degrees has come from the Fiji Times, the Fiji Media Council, the Fijian Association Party, the Fiji Labour Party, the National Federation Party, Pacific Media Watch and the Pacific Islands News Association among others.

The Fiji Media Council has described the move as "a serious threat to media independence." Opposition leader Jai Ram Reddy points out that the buy out 


\section{INGRID LEARY}

seems hypocritical when the Government is busy selling off its other state interests.

The Fijian Association Party, which also has its own agenda in challenging the purchase, went so far as to accuse the Government of deliberately taking steps to control the newspaper's editorial policy in the run up to the May election. The Fiji Labour Party agreed with this conclusion, saying the Government wanted to use the newspaper as a "mouthpiece" during the following critical two months.

The Finance Minister, Jim Ah Koy, has defended the buy out, saying it was good for individual citizens who might eventually get to own shares in the company. With talk of an office revamp to improve the facilities and conditions of work for staff, the purchase might seem to make good business sense.

Anyone who has visited the tired old Post offices would probably agree that a change of location and some serious financial investment might lift staff morale and maybe result in more advertising and circulation. If the Post were solely a business.

But it's not. It's a newspaper with a mandate to balance the power of the Government and the courts (as much as is possible) so that you and I can be better informed as to what is going on.

Ah Koy has assured the public that there will be no influencing editorial policy. He cites Government shareholdings in Communications Fiji and Fiji Television as examples of non-intervention in state-owned news organisations. And that's where his logic doesn't work.

Even if the Government upholds it's promise to stay out of the newspaper's day to day activities, as appears to be the case so far, the public can no longer have the same confidence in the impartiality of the newspaper. When it comes to "independence" two issues usually arise together: the need for independence and the need to be seen to be independent.

In other words, once public confidence about the independence of a newspaper is lost, it makes no difference whether editorial policy remains devoid of interference. Media is all about communication. And communication only occurs when there is "listening". A Government-owned media organisation will never enjoy the same listening as a privately-owned company, because credibility and independence are integral to each other.

If the Government already owns the majorholdings in the only television station and one of the two radio networks, that's even more reason to keep the independence of the two newspapers intact. 


\section{MEDIA BUY OUTS}

If this were truly just a business deal, the Fiji Times would be celebrating the fact that its competitor was exposed to a credibility crisis - after all, that would eventually mean more revenue to the Times.

Instead, a Times editorial questioned the timing on the eve of general elections as "suspicious" and the intention "dubious." The editorial reminded the minister that government-controlled newspapers did not have a history of success, and speculated that the purchase might in fact devalue the newspaper.

Another development threatening media freedom in the region has come not from a government, but from the courts. In Samoa, a last-minute court injunction prevented distribution of the Samoa Observer newspaper after it had already been printed.

The Supreme Court judge, Andrew Bray Cameron Wilson, said he was satisfied that the granting of the order was necessary to prevent irreparable damage to the Polynesian Airlines, owned by the Samoan Government. The newspaper article alleged that 21 senior staff were given advances and allowances totalling nearly US\$250,000 in 1997 and 1998. The newspaper had extensive paperwork on the deals, including cheque numbers and leaked documents, which had been confirmed as authentic. The story carried a denial from the airline management that anything unlawful had occurred.

To slap a gagging order on a newspaper in circumstances where there were clearly serious questions regarding the advances is alarming. Even if the airline were able to justify the advances - which remains to be seen - the media should at least be able to raise questions about the use of public money. The court decision delivers another major financial blow to the newspaper's awardwinning editor and publisher, Savea Malifa, who is already crippled by a series of high-cost legal actions mounted by the Samoan Government.

Even worse, the decision sends a signal to the region that the courts in Samoa are not all that interested in allowing a forum for public questioning and debate. Had the story proven incorrect, the airline would have probably been entitled to hundreds of thousands of dollars damage - potentially spelling the end of Malifa's newspaper. The fact that Malifa was prepared to publish under that sort of pressure suggests that he had information worth sharing.

At least in Fiji when serious questions arise - such as the timing of the Post purchase - we still enjoy the freedom of expression allowed in columns such as this one, letters to the editor and editorials. It is the continuation of these forums, which will give weight to Jim Ah Koy's words. Watch this space! 


\section{INGRID LEARY}

$\square$ Ingrid Leary is a Lecturer in Journalism at the University of the South Pacific and writes a weekly column, "Media Watch", in Fiji's Daily Post. This column appeared under the title, "Is freedom of the press really free?", on 3 March 1999.

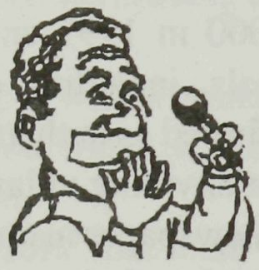

\section{PACIFIC MEDIA WATCH}

'The work of Pacific Media Watch is vital to understanding of the media and the problems of press freedom in this part of the world, about which, all too often, little is known. Reporters Sans Frontières has been working with PMW for more than four years. This has enabled us, whenever necessary, to warn international media of the difficulties that journalists may meet in the South Pacific region.'

Daily list serve: Email: niusedita@ pactok.net.au

Website: http://www.pactok.net.au/docs/pmw/ c/- Journalism Programme, University of the South Pacific,

PO Box 1168, Fax: (679) 313238, Suva, Fiji, or

Bushfire Media, PO Box 9, Annandale, NSW 2038 